Egypt. J. of Appl. Sci., 36 (7-8) 2021

\title{
EFFECT OF BIOFERTILIZATION AND COMPOST LEVELS ON PRODUCTIVITY OF SOME FODDER CROPS UNDER SALINE STRESS
}

Amal E. Ahmed and Mona M. El-Shazly*

Soil Fertility \& Microbiology Dept.

Desert Research Center, Cairo, Egypt.

*E-mail - monaelshazly2011@gmail.com

Key Words: Compost, Biofertilization, Sorghum, Azotobacter chroococcum, Azospirillum brasilence, Organic matter, Salinity.

\begin{abstract}
This study was carried out to develop a technique for improving the productivity of some summer fodder crops under salinity stress condition. Field analysis and estimations were done for two progressive seasons (2016 and 2017) at South Sinai Reaserch Station, Ras Sudr, Desert Research Center, to consider the impact of biofertilizer application and compost rates in enhancing some summer fodder crops. The utilized biofertilizers were A. chroococcum and Azospirillum brasilense single and mixed treatments with two compost rates(10 and $20 \mathrm{~m}^{3} /$ Fed.).

Analysis of the manure, the soil microbiological properties and physicochemical analysis of compost showed a highly efficient compost productivity was obtained with narrow $\mathrm{C} / \mathrm{N}$ ratio and rich microbial counts. Soil microbial properties and production of some fodder crops (Maruit 1, Black suddan grass and Pearl millet) irrigated with saline water were measured. Obtained results showed that, there was a superiority of mixed biofertilization treatments over all individual with $20 \mathrm{~m}^{3}$ followed by mixed with $10 \mathrm{~m}^{3}$ compost when compared with all individual treatments. Increase in compost rate increased significantly all the studied parameters. A. chroococcum and Azospirillum brasilense played an energizing role especially with application of compost. Also, results indicated that, the three studied Sorghum varieties differed significantly in their responses to biofertilization treatments and organic matter (compost levels). Highest obtained values of all parameters were recorded with Maruit-1 followd by pearl millet. Also, mixed treatments with Azotobacter chroococcum and Azospirillum brasilence recorded the highest activity to alleviate salt stress compared with single and control. It can concluded that, organic matter application at $20 \mathrm{~m}^{3} / \mathrm{fed}$ with mixed biofertilization treatments improve yield, its components and stimulate microbial and enzymatic activity in rhizosphere of the studied fodder crops under salinity stress compared with all the other treatments.
\end{abstract}




\section{INTRODUCTION}

Biofertilizer is a wide term, which includes a diverse category of bioinoculants such as nitrogen fixers, phosphate solubilizers, phosphate mobilizers and plant growth promoting rhizobacteria. Numerous bacterial species have found as PGPR mainly Azotobactor, Azosprillium, Bacillus, Pseudomonas etc. The application of these bacterial species as biofertilizers could be the alternate source of synthetic fertilizers because these bacterial species have great potential to fix atmospheric nitrogen as well as to solubilize the phosphorus in the soil. Azotobacter and Azospirillum genera are free-living bacteria and fix atmospheric nitrogen in cereal crops without any symbiosis. They fix 20-40 $\mathrm{kg} \mathrm{ha}^{-1}$. Azotobacter sp. also has ability to produce antifungal compounds against many plant pathogens. Thus, biofertilizers containing beneficial organisms that are cost effective, pollution free and a perennially renewable source of plant nutrients, making them ideal partners and essential supplements to chemical fertilizers (EI-Latief, 2016). Biofertilizers like Azospirillum may release phytohormones like auxin which enhance root branching and also root elongation. This would be a clear advantage for plants in dry areas (Steenhoudt and Vandereyden, 2000). Furthermore, biofertilizers are able to produce other plant hormones like gibberellins and cytokinins in the case of Azotobacter (Bhardwai et al., 2014).

Inoculation of PGPR can increase plant uptake from several nutrients such as $\mathrm{Ca}, \mathrm{K}, \mathrm{Fe}, \mathrm{Cu}, \mathrm{Mn}$ and $\mathrm{Zn}$. This uptake usually occurs during acidification of the soil rhizosphere via organic acid production or via stimulation of proton pump ATP ase (Mantelin and Touraine, 2004).

Soil salinity is an increasing problem in the world and main obstacle to agricultural productivity especially in areas where irrigation is necessary. It adversely affects plant growth and development. Adoption of salt tolerant variety is more important here and so screening of salt tolerant germplasms is essential (Roy et al., 2018). Salinity is one of the major abiotic stresses in agriculture worldwide, limiting crop productivity (Munns and Tester, 2008). Globally, a total land area of 831 million hectares is affected by salinity (Turkan and Demiral, 2009; Munns, 2005). Salt accumulation is mainly related to a dry climate, salt rich parent materials of soil formation, insufficient drainage and irrigation with saline ground water (Almodares, et al., 2008). 
The adverse physiological effects may be attributed to unavailability to water, reduction in photosynthesis through loss of turgidity, impeded nutrient uptake causing deficiency and ion toxicity to plants (Niu, et al.,2012 ;Munns and Tester, 2008; Netondo et al., 2004a، 2004b). Salt stress may also impair synthesis of biochemical substances such as enzymes, sugars and protein (Singh and Chatrath., 2001). During salinity stress decrease in $\mathrm{K}^{+}$and $\mathrm{Ca}^{2+}$ and accumulation of $\mathrm{Na}^{+}$and $\mathrm{Mg}^{2+}$ ions in both roots and shoots occurs in plant body (Farooq et al., 2015; Yasmeen et al., 2013). Also, causing reduction in dry matter accumulation and grain yield (Flowers and Flowers 2005).

Sorghum (Sorghum bicolor L.) is the fourth most important cereal crop grown in the world. Sorghum is grown on approximately 44 million hectares in 99 countries. (FAOSTAT, 2013).Sorghum has potential uses such as: food (grain), feed )grain and biomass), fuel (ethanol production), fiber paper, fermentation (methane production) and fertilizer utilization of organic byproducts. Sorghum is a principal source of energy, protein, vitamins and minerals for millions of the poorest people in the semi arid regions (Khaton et al., 2016). The protein content of sorghum (11.3\%) is nearly equal and is comparable to that of wheat and maize. Average starch content of the seeds range from 56to $73 \%$ and is relatively rich in iron, phosphorous and vitamin B-complex (Reddy et al.,2010). From the microbiological point of view' green manure has two main positive effects, i.e. it provides nutrient rich in organic carbon for the microbial biomass, which converts unavailable nutrients in plant residues to ones available for crops at it enhances biodiversity of soil microorganisms(Abd El Gawad,2008). Azim, et al., (2018) reported that the role of compost in salt-affected soils is very vital because the organic source is ultimate opportunity to improve the physical properties of soils, which have been deteriorated to the extent that water and air passage become extremely difficult in such soils .

The main objective of the present study was to examine the effect of biofertilization and compost levels on the productivity of some fodder crops under saline stress

\section{MATERIALS AND METHODS}

A field experiments were conducted during two successive seasons at Ras Sudr Research Station, South Sinai Governorate to study the effect of different rates of compost and different biofertilization treatments, i.e. Azotobacter chroococcum, Azospirillum brasilensce and the mixture of them on the productivity of some summer forage crops namely 
Maruit-1, black Sudan grass and pearl millet under soil and water saline conditions.

Physical properties and chemical analysis of soil and irrigation water are presented in Table 1 and Table 2.

Table (1). Some physical and chemical properties of the experimental soil.

\begin{tabular}{|c|c|c|c|c|c|c|c|c|c|}
\hline \multirow{2}{*}{$\begin{array}{c}\text { Depth } \\
\text { Cm }\end{array}$} & \multirow[b]{2}{*}{ pH } & \multirow{2}{*}{$\begin{array}{c}\text { EC soil } \\
\text { paste } \\
\text { dS/m } \\
\end{array}$} & $\mathbf{O M}$ & $\mathrm{CaCO}_{3}$ & Sand & Silt & Clay & \multirow{2}{*}{$\begin{array}{c}\text { CEC } \\
\text { Cmole/ } \\
\text { kg soil } \\
\end{array}$} & \multirow[b]{2}{*}{ Texture } \\
\hline & & & \multicolumn{5}{|c|}{$\%$} & & \\
\hline 0-30 & 7.73 & 8.56 & 2.28 & 26.9 & 75.5 & 12.57 & 11.93 & 5.81 & $\mathbf{L S}$ \\
\hline $30-60$ & 7.96 & 7.35 & 1.73 & 27.4 & 73.4 & 15.31 & 11.29 & 6.65 & $\mathbf{L S}$ \\
\hline \multicolumn{10}{|c|}{ Cations and anions in soluble soil $(\mathrm{meq} / \mathrm{L})$} \\
\hline Depth & $\mathrm{Na}^{+}$ & $\mathbf{K}$ & & $\mathrm{Ca}^{+2}{ }^{+2}$ & $\mathrm{Mg}^{+2}$ & $\mathrm{CO}_{3}{ }^{=}$ & $\mathrm{HCO}_{3}^{-}$ & $\mathrm{Cl}^{-}$ & $\mathrm{SO}_{4}{ }^{=}$ \\
\hline 0-30 & 65.2 & & & 23.9 & 9.5 & $\mathbf{0}$ & 19.4 & 58.7 & 21.8 \\
\hline $30-60$ & 62.94 & 3. & & 22.57 & \begin{tabular}{|l|l|}
10.23 & \\
\end{tabular} & $\mathbf{0}$ & 16.55 & 56.5 & 23.5 \\
\hline \multicolumn{10}{|c|}{ Available nutrients in soil (ppm) } \\
\hline Depth & $\mathbf{N}$ & $\mathbf{P}$ & & $\mathbf{K}$ & \begin{tabular}{|l|l} 
Fe & \\
\end{tabular} & Mn & $\mathbf{Z n}$ & $\mathbf{C u}$ & B \\
\hline $0-30$ & 36.8 & 5.1 & & 48.5 & 4.26 & 2.18 & 1.25 & 0.57 & 0.18 \\
\hline $30-60$ & 21.5 & 3.8 & & 52.3 & 4.64 & 2.23 & 1.31 & 0.66 & 0.12 \\
\hline
\end{tabular}

Table (2). Some chemical properties of the irrigation water at Ras Sudr Research Station.

\begin{tabular}{|c|c|c|c|c|c|c|c|c|c|}
\hline \multirow{2}{*}{$\mathrm{pH}$} & $\begin{array}{c}\mathrm{EC} \\
\mathrm{dS} / \mathrm{m}\end{array}$ & $\mathrm{Na}^{+}$ & $\mathrm{K}^{+}$ & $\mathrm{Ca}^{+2}$ & $\mathrm{Mg}^{+2}$ & $\mathrm{CO}_{3}{ }^{+}$ & $\mathrm{HCO}_{3}{ }^{-}$ & $\mathrm{Cl}^{-}$ & $\mathrm{SO}_{4}{ }^{+}$ \\
\hline 7.94 & 7.85 & 46.9 & $\mathbf{2 . 6 2}$ & $\mathbf{2 0 . 5}$ & $\mathbf{8 . 4 8}$ & $\mathbf{0 . 0 0}$ & $\mathbf{6 . 3}$ & $\mathbf{4 7 . 5}$ & $\mathbf{2 4 . 7}$ \\
\hline
\end{tabular}

\section{Preparation of Compost: \\ Preparation of substrate:}

Substrates such as plant residues, weeds and grasses should be chopped. Chopping helps speed up decomposition by increasing the surface area available for microbial action and providing better aeration. The harder or wooden the tissues, the smaller they need to be decomposed rapidly. Woody material should be passed through a grinder. All existed agricultural wastes were subjected to analysis before composting for $\mathrm{C} / \mathrm{N}$ ratio which was as follow:

Sheep manure used as an initiative material had values: O.C: 19.46 $\%$, T.N: $1.4 \%$, C/N:13.9, O.M ،\%33.5:moisture 28.7 and PH 7.6

\section{Composting Method:}

This method involves digging a pit $(360 \mathrm{~cm}$ long $\times 180 \mathrm{~cm}$ wide $\times 90 \mathrm{~cm}$ deep) in a shaded area (length can vary according to the volume of waste materials available). Farm wastes such as vegetable refuse, weeds, leaves and grasses are spread to a thickness of 15-20 cm. fresh liquid culture of cellulose decomposing bacteria were activated with molass (2 liter bacteria $10^{8} \mathrm{cfu} / \mathrm{ml}+1$ liter molass and 97 litre water for each ton of wastes) and added to facilitate and activate decomposing 
process. Wet animal dung is spread over this layer to a thickness of $5 \mathrm{~cm}$. Water is sprinkled to moisten the material (50-60 percent of mass). This procedure is repeated until the whole mass reaches a height of $60 \mathrm{~cm}$ above ground. It is then covered with plastic sheet . In four weeks, the mass becomes reduced and the heap flattens. The cover plastic is removed and the entire mass is turned Aerobic decomposition commences at this stage, Beneficial soil microorganisms was added to enrich bio-compost with nutrients and other important secretion. Water is sprinkled to keep the material moist. The compost is ready for use after four months Russel,1991.

\section{Compost Enrichment:}

Farm compost is poor in $\mathrm{P}$ content (0.4- $0.8 \%$ ).Addition of $\mathrm{P}$ makes the compost more balanced, and supplies nutrient to microorganisms for their multiplication and faster decomposition. The addition of $\mathrm{P}$ also reduces $\mathrm{N}$ losses.

Compost can be enriched by application of calcium ammonium nitrate $(33.3 \% \mathrm{~N})$ and calcium super phosphate $\left(15.5 \% \mathrm{P}_{2} \mathrm{O}_{5}\right)$ were added in concentrations of $20 \mathrm{Kg} /$ ton and $5 \mathrm{Kg} /$ ton as sources of nitrogen and phosphorous, respectively.Calcium carbonate was added in concentration of $20 \mathrm{Kg}$ / ton to neutralize the $\mathrm{pH}$ of compost.

\section{Microbial Preparation:}

Fresh liquid culture strains of highly efficient for nitrogen fixation, i.e. Azotobacter chrococcum and Azospirillum brasilense that previously isolated and identified and were used for seed inoculation, liquid cultures of Azotobacter chrococcum and Azospirillum brasilense $10^{8} \mathrm{cfu} / \mathrm{ml}$ were applied. The experiment was conducted in split-split plot design, with three replicates.

Compost was added at two rates $\left(10\right.$ and $\left.20 \mathrm{~m}^{3} / \mathrm{fed}\right)$, biofertilization treatments added to soil after germination throughout two weeks after each cut

Grains were planted at four rows with $20 \mathrm{~cm}$ apart. All plots received $31 \mathrm{~kg} \mathrm{P}_{2} \mathrm{O}_{5} / \mathrm{fed}$, as calcium super phosphate, $70 \mathrm{~kg} \mathrm{~N} / \mathrm{fed}$. as ammonium nitrate $(33.5 \% \mathrm{~N})$. Samples of ten plants were taken after 55, 110 and 160 days from planting for the $1^{\text {st }}, 2^{\text {nd }}$ and $3^{\text {rd }}$ cuts, respectively, to assessment plant height and fresh yield.

Chemical analysis of soil was carried out to determine total nitrogen in soil was determined according to Page et al.,(1982), Nitrogen in leaves was determined according to Bremner and Mulvaney, (1982), protein by multiplying nitrogen 6.25

Microbiological analysis: Nutrient modified Bunt and Rovira media, Ashbys and Doberiner media were used for total microbial, phosphate solubilizing bacteria (PSB) counts, Azotobacter and Azospirillum densities, respectively. Dehydrogenase activity according to method 
described by (Casida et al.,1964). Nitrogenase activity was determined according to (Haahtela et al., 1981).

Statistical analysis: Analysis of variance was calculated according to the method of Duncan's, multiple range tests at 0.05 level, using MSTAT computer statistical software according to Russel, (1991).

\section{RESULTS AND DISCUSSION}

1.Physicochemical and microbiological analysis of the obtained Compost:

The rapid decomposition can be detected by a pleasant odour, by the heat produced, by the growth of white fungi on the decomposing organic material, by a reduction of volume, and by the materials changing colour to dark brown. As near completion, the temperature drops and finally little or no heat is produced. The compost is then ready to use. Table (3) showed the physicochemical and microbiological analysis of resulted compost. It is clear that all macro and micronutrients, are in the accepted ranges. Both $\mathrm{N}$ content and $\mathrm{C} / \mathrm{N}$ ratio are very close to the reported values by El-Sersawy et al.(1995). Microbial examination of the obtained compost revealed the increase in numbers of beneficial microorganisms like azotobacters, phosphate dissolving fungi, aerobic cellulose decomposers and total microbial counts, despite absence of pathogenic microorganisms and nematodes. These results are in compatible with Indira, and Singh(2014).

The quality of compost can be further improved by secondary inoculation of Azotobacter chroococcum, and Phosphate dissolving fungi. These microorganisms, can be sprinkled when the decomposing material is turned after one month. As a result of this inoculation, the $\mathrm{N}$ content of compost can be increased by up to $2 \%$. In addition to improving $\mathrm{N}$ content and the availability of other plant nutrients, these additions help to reduce the composting time considerably (Abd EIGawad,2008).

Table (3).Physico-chemical and microbiological analysis of the used compost:

\begin{tabular}{|c|c|c|c|c|c|c|c|c|c|}
\hline \multirow[t]{3}{*}{ Sample } & \multirow[t]{3}{*}{ pH } & \multirow[t]{3}{*}{$\mathrm{C} \%$} & \multicolumn{6}{|c|}{ Total nutrients } & \multirow[t]{3}{*}{$\mathrm{C} / \mathrm{N}$ ratio } \\
\hline & & & $\mathbf{N}$ & $\mathbf{P}$ & $\mathbf{K}$ & $\mathbf{F e}$ & Mn & Zn & \\
\hline & & & \multicolumn{3}{|c|}{$\%$} & \multicolumn{3}{|c|}{ Ppm } & \\
\hline Compost & 7.6 & 28.1 & 0.83 & 0.17 & $\mathbf{0 . 3 5}$ & 749 & 71.5 & 13.1 & 29.2 \\
\hline \multicolumn{10}{|c|}{ Microbiological analysis } \\
\hline \multicolumn{10}{|c|}{ Microbiological determinations (C.F.U/g dry matter) } \\
\hline \multirow{2}{*}{\multicolumn{5}{|c|}{$\begin{array}{ll}\text { Total microbial counts } & \times 10^{5} \\
\text { Azotobacter densities } & \times 10^{3}\end{array}$}} & \multicolumn{4}{|c|}{230} & \\
\hline & & & & & \multirow{2}{*}{\multicolumn{4}{|c|}{51}} & \\
\hline \multicolumn{5}{|c|}{ Phosphate dissolving fungi (PDB) $\times 10^{2}$} & \multirow{2}{*}{\multicolumn{4}{|c|}{54}} & \\
\hline \multicolumn{5}{|c|}{ Cellulose decomposers $\times 10^{4}$} & & & & & \\
\hline \multicolumn{5}{|c|}{$\mathrm{CO}_{2}$ evolution } & 28 & \multicolumn{3}{|c|}{$\left(\mathrm{mg} \mathrm{CO}_{2} / 100 \mathrm{~g}\right.$ dry soil $\left./ 24 \mathrm{hr}\right)$} & \\
\hline
\end{tabular}

2.Effect of Organic Matter Rates, Biofertilization on plant height,fresh and dry yield of the studied forage crops.

The effect of compost rates $\left(10\right.$ and $\left.20 \mathrm{~m}^{3}\right)$ application with the studied three biofertilization treatments on plant height, fresh and dry yield among the three studied forage crops was presented in Table (4). Results reported 
that, bacterial inoculation recorded significant increases for all the measured parameters. Maximum stimulatory effect of the biofertilizers was existed in plant treated with mixture of both A. chroococcum and A. brasilensce at $20 \mathrm{~m}^{3}$ rate of compost. Significant differences were obtained between the three used fodder crops in all studied traits and were observed by applied treatments. It would be concluded that the genotypes difference between the three fodder crops may be due to genetically difference between genotypes and the difference between genotypes concerning partition of dry matter. These obtained results of genotypes differences on the studied traits are in agreement with those obtained by Muchow, (1989), Zerbini, and Thomas, (2003).

Table (4). Effect of Compost Rates and Biofertilization on plant height and fresh yield for of the studied fodder crops under salt stress

\begin{tabular}{|c|c|c|c|c|c|c|c|c|c|c|c|}
\hline \multirow[t]{2}{*}{ Genotypes } & \multirow[t]{2}{*}{ OM } & \multirow{2}{*}{$\begin{array}{l}\text { Biofertilization } \\
\text { Treatments }\end{array}$} & \multicolumn{3}{|c|}{ Plant height (cm) } & \multicolumn{3}{|c|}{ Fresh weight (Ton/fed. } & \multicolumn{3}{|c|}{\begin{tabular}{|c|}
$\begin{array}{c}\text { Dry weight } \\
\text { (Ton/fed.) }\end{array}$ \\
\end{tabular}} \\
\hline & & & Cut $_{1}$ & $\mathrm{Cut}_{2}$ & $\mathrm{Cut}_{3}$ & $\mathrm{Cut}_{1}$ & $\mathrm{Cut}_{2}$ & $\mathrm{Cut}_{3}$ & $\mathrm{Cut}_{1}$ & $\mathrm{Cut}_{2}$ & $\mathrm{Cut}_{3}$ \\
\hline \multirow{8}{*}{ 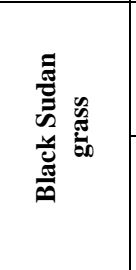 } & \multirow{4}{*}{10} & Control & 109 & 98 & 94 & 2.29 & 2.1 & 1.84 & 0.31 & 0.39 & 0.32 \\
\hline & & Azotobacter & 135 & 130 & 126 & 2.89 & 2.92 & 2.73 & $\mathbf{0 . 3 9}$ & 0.47 & 0.43 \\
\hline & & Azospirillm & 131 & 128 & 122 & 2.75 & 2.58 & 2.46 & 0.42 & 0.52 & 0.48 \\
\hline & & Mixture & 148 & 139 & 137 & 3.76 & 4.19 & 3.95 & 0.75 & 0.91 & 0.79 \\
\hline & \multirow{4}{*}{20} & Control & 127 & 128 & 123 & 2.53 & 2.46 & 2.39 & 0.38 & 0.46 & 0.42 \\
\hline & & Azotobacter & 209 & 194 & 186 & 5.27 & 5.14 & 5.03 & 0.51 & 0.64 & 0.61 \\
\hline & & Azospirillm & 183 & 182 & 174 & 4.91 & 4.89 & 4.61 & 0.53 & 0.67 & 0.63 \\
\hline & & Mixture & 219 & 212 & 209 & 5.81 & 5.59 & 5.48 & 0.89 & 0.96 & 0.87 \\
\hline \multirow{8}{*}{ 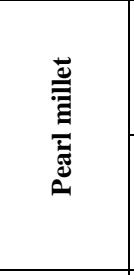 } & \multirow{4}{*}{10} & Control & 103 & 101 & 99 & 1.32 & 1.26 & 1.12 & 0.33 & 0.45 & 0.41 \\
\hline & & Azotobacter & 127 & 125 & 112 & 2.05 & 2.81 & 2.64 & 0.48 & 0.55 & 0.49 \\
\hline & & Azospirillm & 120 & 116 & 104 & 1.95 & 2.63 & 2.37 & 0.49 & 0.58 & 0.56 \\
\hline & & Mixture & 136 & 133 & 127 & 2.24 & 3.69 & 3.41 & 0.88 & 0.94 & 0.91 \\
\hline & \multirow{4}{*}{20} & Control & 118 & 112 & 110 & 1.89 & 1.83 & 1.68 & 0.41 & 0.49 & 0.43 \\
\hline & & Azotobacter & 139 & 135 & 129 & 3.59 & 4.28 & 4.11 & 0.69 & 0.78 & 0.71 \\
\hline & & Azospirillm & 131 & 127 & 121 & 3.37 & 3.98 & 3.80 & 0.73 & 0.85 & 0.77 \\
\hline & & Mixture & 150 & 141 & 129 & 4.52 & 5.41 & 5.15 & 1.02 & 0.99 & 0.94 \\
\hline \multirow{8}{*}{ 意 } & \multirow{4}{*}{10} & Control & 107 & 103 & 98 & 1.7 & 1.62 & 1.54 & 0.33 & 0.47 & 0.45 \\
\hline & & Azotobacter & 130 & 130 & 123 & 2.44 & 2.89 & 2.6 & 0.54 & 0.62 & 0.59 \\
\hline & & Azospirillm & 129 & 127 & 124 & 2.25 & 2.64 & 2.42 & $\mathbf{0 . 5 9}$ & 0.65 & 0.63 \\
\hline & & Mixture & 140 & 135 & 125 & 3.31 & 3.92 & 3.57 & 0.93 & 1.08 & 0.92 \\
\hline & \multirow{4}{*}{20} & Control & 124 & 119 & 113 & 1.79 & 1.72 & 1.63 & 0.45 & $\mathbf{0 . 5 1}$ & 0.47 \\
\hline & & Azotobacter & 169 & 161 & 157 & 3.91 & 5.64 & 5.22 & 0.66 & 0.79 & 0.75 \\
\hline & & Azospirillm & 161 & 156 & 142 & 3.87 & 5.61 & 5.39 & 0.68 & 0.84 & $\mathbf{0 . 8 1}$ \\
\hline & & \begin{tabular}{|l} 
Mixture \\
\end{tabular} & 188 & 186 & 170 & 4.68 & 6.22 & 5.91 & 1.16 & 1.23 & 1.08 \\
\hline \multicolumn{3}{|c|}{ L.S.D at $0.05 \%$ interaction } & \multicolumn{3}{|c|}{2.063} & \multicolumn{3}{|c|}{0.129} & \multicolumn{3}{|c|}{0.0551} \\
\hline
\end{tabular}

3.Effect of compost rate and biofertilization treatments on yield of some fodder crops under salt stress

Data in Table (5) clearly showed that the biofertilization treatments have resulted in increase of grain/panicle and grain yield Ton/fed. It was clear that there is a gradual increase in yield with the different biofertilization treatments from single to the mixed treatment. Mixed biofertilization treatment resulted to the highest significant increase in 
grain yield of Maruit-1 which recorded $112.8 \%$ followed by pearl millet $94.3 \%$ and Black Sudan grass $84.7 \%$ of increase in grain yield over control in descending order at compost level $20 \mathrm{~m}^{3}$. Synergistic effect between biofertilizers in mixed treatment positively affected grain yield. These results may be attributed to the differences among the studied forage crops in yield and its components as the differences in genetically contents of the three forage crops. Maruit-1 may be more adapted to salinity and drought conditions. So, it is considered a favorable forage crops under Ras Sudr conditions. These results are in agreement with those reported by El-Sherbiny, and Abed El- Lateef, (2009). High yield obtained with compost level $20 \mathrm{~m}^{3}$ was applied and with Maruit-1 and the other tested forage crops. There was a significant effect among biofertilization, compost levels and forage crops on the studied traits obviously with the mixed biofertilization treatments which gave the maximum effect on yield of the studied forage crops. The same trend was obtained by Kim, et. al. (2000),

Table (5). Effect of Compost Rates and Biofertilization on plant height and fresh yield for of some fodder crops under salt stress

\begin{tabular}{|c|c|c|c|c|}
\hline Genotypes & OM & $\begin{array}{l}\text { Biofertilization } \\
\text { Treatments }\end{array}$ & $\begin{array}{c}\text { Grain weight } \\
\text { (g/plant) }\end{array}$ & $\begin{array}{c}\text { Grain yield } \\
\text { (Ton/fed.) }\end{array}$ \\
\hline \multirow{8}{*}{ 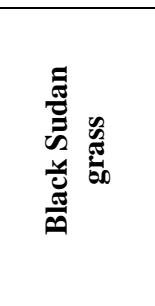 } & \multirow{4}{*}{10} & \begin{tabular}{|l|} 
Control \\
\end{tabular} & 29.7 & 1.31 \\
\hline & & Azotobacter & 40.2 & 1.86 \\
\hline & & Azospirillm & 44.9 & 1.91 \\
\hline & & Mixture & 49.5 & 1.97 \\
\hline & \multirow{4}{*}{20} & Control & 34.1 & 1.45 \\
\hline & & Azotobacter & 45.3 & 2.08 \\
\hline & & Azospirillm & 47.5 & 2.17 \\
\hline & & Mixture & 54.2 & 2.42 \\
\hline \multirow{8}{*}{ 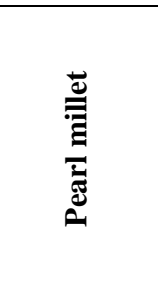 } & \multirow{4}{*}{10} & Control & 30.1 & 1.41 \\
\hline & & Azotobacter & 45.8 & 2.15 \\
\hline & & Azospirillm & 48.1 & 2.29 \\
\hline & & Mixture & 56.2 & 2.41 \\
\hline & \multirow{4}{*}{20} & Control & 37.3 & 1.82 \\
\hline & & Azotobacter & 50.8 & 2.51 \\
\hline & & Azospirillm & 53.2 & 2.58 \\
\hline & & Mixture & 59.1 & 2.74 \\
\hline \multirow{8}{*}{ 总 } & \multirow{4}{*}{10} & Control & 31.1 & 1.64 \\
\hline & & Azotobacter & 51.6 & 2.78 \\
\hline & & Azospirillm & 54.7 & 2.85 \\
\hline & & Mixture & 56 & 3.06 \\
\hline & \multirow{4}{*}{20} & Control & 39 & 2.19 \\
\hline & & Azotobacter & 53.9 & 3.11 \\
\hline & & Azospirillm & 58 & 3.25 \\
\hline & & Mixture & 62.1 & 3.49 \\
\hline \multicolumn{3}{|c|}{ L.S.D at $0.05 \%$} & 1.294 & 0.269 \\
\hline
\end{tabular}


4.Effect of compost rate and biofertilization treatments on total nitrogen in soil, nitrogen and protein in leaves for some fodder crops under salt stress

Data presented in Table (6) showed that nitrogen contents in soil at three cuts, indicated that nitrogen content in soil was significantly affected by the applied treatments and the three fodder crops. Maruit-1 which gave highest concentration (174ppm), followed by 173 and 170 for pearl millet and Black Sudan grass respectively. These forage crops may be adapted to drought and salinity conditions. So, it is considered as a favorable forage crop under Ras Sudr conditions. These results are in agreement with those represented by Ague and Palmer (2007).

For biofertilizer applications treatments, data indicated that inoculation process increased $\mathrm{N}$ and protein content in leaves. Inoculation with A. chroococcum and Azospirillum brasilensce singly or mixed cause highest $\mathrm{N}_{2}$ fixation compared with control. Thus, Azotobacter and Azospirillum enriched the soil by nitrogen fixation and other different activities which increased soil fertility.

Table (6): Effect of organic mtter rate and biofertilization treatments and micronutrients on total nitrogen in soil, nitrogen and protein in leaves of the fodder crops. (Average of two seasons2016 and 2017)

\begin{tabular}{|c|c|c|c|c|c|c|c|c|c|c|c|}
\hline \multirow{2}{*}{ Genotypes } & \multirow{2}{*}{ OM } & \multirow{2}{*}{$\begin{array}{l}\text { Biofertilization } \\
\text { treatments }\end{array}$} & \multicolumn{3}{|c|}{$\mathrm{N}$ in soil(ppm) } & \multicolumn{3}{|c|}{$\mathrm{N}$ in leaves $(\%)$} & \multicolumn{3}{|c|}{ Protein ( \% ) } \\
\hline & & & Cut $_{1}$ & $\mathrm{Cut}_{2}$ & $\mathrm{Cut}_{3}$ & $\mathrm{Cut}_{1}$ & $\mathrm{Cut}_{2}$ & $\mathrm{Cut}_{3}$ & Cut $_{1}$ & $\mathrm{Cut}_{2}$ & Cut \\
\hline \multirow{8}{*}{ 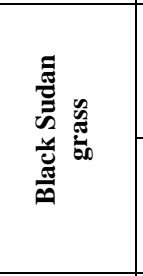 } & \multirow{4}{*}{10} & Control & 115 & 128 & 121 & 0.91 & 0.96 & 0.94 & 5.7 & 6.0 & 5.9 \\
\hline & & Azotobacter & 122 & 132 & 127 & 0.98 & 1.12 & 1.05 & 6.1 & 7.0 & 6.6 \\
\hline & & Azospirillm & 123 & 139 & 129 & 0.94 & 1.06 & 0.93 & 5.9 & 6.6 & 5.8 \\
\hline & & Mixture & 130 & 149 & 141 & 1.12 & 1.18 & 1.11 & 7.0 & 7.4 & 6.9 \\
\hline & \multirow{4}{*}{20} & Control & 126 & 138 & 130 & 1.071 & 1.113 & 1.052 & 6.7 & 7.0 & 6.6 \\
\hline & & Azotobacter & 147 & 151 & 146 & 1.281 & 1.307 & 1.3755 & 8.0 & 8.2 & 8.6 \\
\hline & & Azospirillm & 148 & 153 & 147 & 1.239 & 1.386 & 1.3335 & 7.7 & 8.7 & 8.3 \\
\hline & & Mixture & 152 & 170 & 161 & 1.3545 & 1.449 & 1.3965 & 8.5 & 9.1 & 8.7 \\
\hline \multirow{8}{*}{ 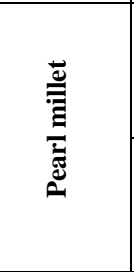 } & \multirow{4}{*}{10} & Control & 117 & 129 & 123 & \begin{tabular}{l|l}
0.94 \\
\end{tabular} & 1.02 & \begin{tabular}{l|l}
0.97 \\
\end{tabular} & 5.9 & 6.4 & 6.1 \\
\hline & & Azotobacter & 125 & 144 & 139 & 1.02 & 1.28 & 1.25 & 6.4 & 8.0 & 7.8 \\
\hline & & Azospirillm & 127 & 148 & 140 & 0.94 & 1.25 & 1.18 & 5.9 & 7.8 & 7.4 \\
\hline & & Mixture & 134 & 152 & 147 & 1.16 & 1.36 & 1.32 & 7.3 & 8.5 & 8.3 \\
\hline & \multirow{4}{*}{20} & Control & 126.4 & 140.8 & 137 & 1.078 & 1.167 & 1.096 & 6.7 & 7.3 & 6.9 \\
\hline & & Azotobacter & 148.3 & 156.5 & 152.9 & 1.353 & 1.454 & 1.399 & 8.5 & 9.1 & 8.7 \\
\hline & & Azospirillm & 149.1 & 155.1 & 147.4 & 1.265 & 1.221 & 1.155 & 7.9 & \begin{tabular}{l|l}
7.6 \\
\end{tabular} & 7.2 \\
\hline & & Mixture & 152.9 & 173.8 & 166.1 & 1.408 & 1.508 & 1.464 & 8.8 & 9.425 & 9.15 \\
\hline \multirow{8}{*}{ 莺 } & \multirow{4}{*}{10} & Control & 120 & 129 & 125 & 0.94 & 1.08 & 0.98 & 5.9 & \begin{tabular}{l|l}
6.8 \\
\end{tabular} & 6.1 \\
\hline & & Azotobacter & 127 & 145 & 134 & 1.05 & 1.32 & 1.26 & 6.6 & 8.3 & 7.9 \\
\hline & & Azospirillm & 128 & 151 & 148 & 0.97 & 1.28 & 1.21 & 6.1 & 8.0 & 7.6 \\
\hline & & Mixture & 138 & 156 & 149 & 1.17 & 1.39 & 1.3 & 7.3 & 8.7 & 8.1 \\
\hline & \multirow{4}{*}{20} & Control & 130 & 142.6 & 139.5 & 1.12 & 1.29 & 1.24 & 7.0 & 8.1 & 7.75 \\
\hline & & Azotobacter & 149.7 & 158.3 & 155.2 & 1.37 & 1.49 & 1.44 & 8.6 & 9.3 & 9 \\
\hline & & Azospirillm & 150.6 & 159.1 & 154.8 & 1.29 & 1.35 & 1.29 & 8.1 & 8.4 & 8.1 \\
\hline & & Mixture & 157 & 174.3 & 169.9 & 1.41 & 1.52 & 1.48 & 8.8 & \begin{tabular}{l|l|}
9.5 \\
\end{tabular} & 9.3 \\
\hline & \multicolumn{2}{|c|}{ S.D at $0.05 \%$} & \multicolumn{3}{|c|}{0.988} & \multicolumn{3}{|c|}{1.03} & \multicolumn{3}{|c|}{0.711} \\
\hline
\end{tabular}


In the present investigation a mixed inoculation of different forage crops with A. chroococcum and Azospirillum enhanced the growth of three forage crops and increased the soil fertility as reflected by soil mineral contents. This result is in compatible with the findings of Ahmed and El-Shazly (2018).

5-Effect of compost rate and biofertilization treatments on $\mathrm{Na}^{+}$and

$\mathrm{K}^{+}$in the studied fodder crops.

Organic matter rates with biofertilization treatments showed a significant effect on the concentration of $\mathrm{Na}^{+}$in roots for the studied different forage crops. Data in (Table 7) indicated that the content of $\mathrm{Na}^{+}$ was strongly affected by the different biofertilization treatments and two organic matter rates. The effect of biofertilization with Azotobacter, Azospirillum and mixed treatment decreased significantly the accumulation of $\mathrm{Na}^{+}$. While $\mathrm{K}$ concentration took the opposite trend. Generally, concentration of $\mathrm{K}^{+}$decreased at third cut. Inoculation with Azotobacter and Azospirillum allowed a better accumulation of $\mathrm{Na}^{+}$. The effect of salt stress increased the absorption of $\mathrm{Na}^{+}$, whereas the absorption of $\mathrm{K}^{+}$decreased in the roots for three forage crops tested. Bhivare and Nimbalkar (1984) found that reducing the amount of $\mathrm{K}^{+}$ and increased the content of $\mathrm{Na}^{+}$could be attributed to the effect of competition between $\mathrm{Na}^{+}$and $\mathrm{K}^{+}$on the sites of absorption in the plant.

6-Effect of compost rate and biofertilization treatments on proline content in three fodder crops under salt stress

Proline is an important biochemical indicator, which is considered as a major osmoregulator in plants under various stresses and very much sought after compatible osmolyte, which help plants to counteract and recovery from salt stress (Kumar et. al., 2010). There was a steep increase in proline content in the different genotypes with different biofertilization treatments as shown in Table (7). Maximum proline content recorded with biofertilizer application especially Azospirllum brasilence. Although Azospirillum was directly related to its ability to fix $\mathrm{N}_{2}$, it also evidenced the multiple capabilities these bacteria have. As well as having the potential to fix $\mathrm{N}_{2}$, they can produce siderophores, bacteriocins, and plant growth hormones (Bashan \& de Bashan, (2010) and Jain et. al., (2010). They can also increase ion absorption (e.g., $\mathrm{K}^{+}$ and $\mathrm{NO}_{3}{ }^{-}$) to avoid plant hydric stress, and modify soil redox potential (Bagheri, (2011); Bashan, et. al., (2004); Hungria et. al., (2010) and Pidello, (2011). 
Table (7). Effect of compost rate and biofertilization treatments on $\mathrm{Na}^{+}, \mathrm{K}^{+}$and proline content in the leaves of the studied fodder crops.

\begin{tabular}{|c|c|c|c|c|c|c|c|c|c|c|c|}
\hline \multirow{2}{*}{ Genotypes } & \multirow{2}{*}{ OM } & \multirow{2}{*}{$\begin{array}{c}\text { Biofertilization } \\
\text { treatments }\end{array}$} & \multicolumn{3}{|c|}{$\mathrm{Na}(\mathrm{mg} / \mathrm{g} \mathrm{dw})$} & \multicolumn{3}{|c|}{$K(\mathrm{mg} / \mathrm{g} \mathrm{dw})$} & \multicolumn{3}{|c|}{ Proline (mg/g fw) } \\
\hline & & & Cut $_{1}$ & $\mathrm{Cut}_{2}$ & $\mathrm{Cut}_{3}$ & Cut $_{1}$ & $\mathrm{Cut}_{2}$ & $\mathrm{Cut}_{3}$ & Cut $_{1}$ & Cut $_{2}$ & $\mathrm{Cut}_{3}$ \\
\hline \multirow{8}{*}{ 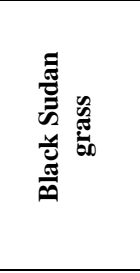 } & \multirow{4}{*}{10} & Control & 36.6 & 40.1 & 42.6 & 3.1 & 3.7 & 3.4 & 3.1 & 3.3 & 3.2 \\
\hline & & Azotobacter & 35.6 & 38.3 & 40 & 4.6 & 4.7 & 4.5 & 4.3 & 4.4 & 4.2 \\
\hline & & Azospirillm & 33.0 & 37.4 & 39.1 & 4.6 & 4.7 & 4.6 & 4.3 & 4.33 & 4.3 \\
\hline & & Mixture & 32.1 & 36.5 & 37.4 & 4.7 & 4.8 & 4.6 & 4.4 & 4.4 & 4.3 \\
\hline & \multirow{4}{*}{20} & Control & 43.5 & 46.6 & 51.94 & 3.4 & 3.8 & 3.6 & 3.8 & 3.7 & 3.5 \\
\hline & & Azotobacter & 42.4 & 44.5 & 48.8 & 5.0 & 5.0 & 4.8 & 4.9 & 5.0 & 4.8 \\
\hline & & Azospirillm & 39.2 & 43.5 & 47.7 & 5.0 & 5.3 & 4.9 & 5.0 & 4.9 & 4.9 \\
\hline & & Mixture & 38.2 & 42.4 & 45.6 & 5.1 & 5.3 & 4.9 & 5.1 & 5.3 & 4.9 \\
\hline \multirow{8}{*}{ 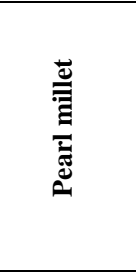 } & \multirow{4}{*}{10} & Control & 39 & 52.7 & 57.0 & 3.3 & 3.8 & 3.7 & 3.5 & 3.3 & 3.3 \\
\hline & & Azotobacter & 42.1 & 48.2 & 53.0 & 4.7 & 4.9 & 4.6 & 4.8 & 5.0 & 5.3 \\
\hline & & Azospirillm & 45.6 & 53.2 & 49.4 & 4.6 & 4.8 & 4.5 & 4.95 & 5.1 & 5.4 \\
\hline & & Mixture & 39.8 & 45.6 & 46.5 & 4.9 & 5.0 & 4.6 & 5.04 & 5.3 & 5.6 \\
\hline & \multirow{4}{*}{20} & Control & 40.0 & 54.2 & 58.71 & 3.6 & 4.2 & 3.9 & 4.3 & 4.1 & 4.1 \\
\hline & & Azotobacter & 43.4 & 49.7 & 54.59 & 4.8 & 5.0 & 4.7 & 5.8 & 5.6 & 5.5 \\
\hline & & Azospirillm & 47.5 & 55.4 & 51.5 & 4.6 & 4.8 & 4.7 & 6.04 & 5.72 & 5.6 \\
\hline & & Mixture & 41.4 & 47.5 & 48.41 & 5.0 & 5.4 & 4.9 & 6.1 & 5.9 & 5.8 \\
\hline \multirow{8}{*}{ 䔍 } & \multirow{4}{*}{10} & Control & 39.7 & 40.7 & 42.6 & 4.0 & 3.9 & 3.9 & 3.6 & 3.4 & 3.4 \\
\hline & & Azotobacter & 37 & 38.8 & 41.6 & 5.2 & 5.1 & 5.0 & 4.9 & 5.2 & 5.5 \\
\hline & & Azospirillm & 34.7 & 39.8 & 40.6 & 5.3 & 5.3 & 5.3 & 5.1 & 5.3 & 5.6 \\
\hline & & Mixture & 34.7 & 36.9 & 38.7 & 5.7 & 5.4 & 5.4 & 5.2 & 5.5 & 5.8 \\
\hline & \multirow{4}{*}{20} & Control & 36.4 & 38.3 & 41.4 & 4.3 & 4.2 & 4.2 & 4.4 & 4.2 & 4.2 \\
\hline & & Azotobacter & 32.3 & 35.3 & 41.4 & 5.6 & 5.5 & 5.4 & 6.0 & 5.8 & 5.7 \\
\hline & & Azospirillm & 35.1 & 37.2 & 40.4 & 5.7 & 5.7 & 5.7 & 6.2 & 5.9 & 5.8 \\
\hline & & Mixture & 31.1 & 33.2 & 38.3 & 6.1 & 5.8 & 5.8 & 6.3 & 6.1 & 6.02 \\
\hline
\end{tabular}

7. Effect of compost levelsand biofertilization on soil microbial activity in rhizosphere of the studied forage crops.

7.1. Total microbial counts: Data presented in Table (8) showed that, the microbial counts in rhizosphere for the studied forage crops varied greatly with different treatments. The initial total microbial counts in soil before cultivation were $47 \times 10^{5} \mathrm{cfu} / \mathrm{g}$ dry soil. Counts were tended to increase with different biofertilization treatments either in single or mixed application. The highest mean counts were associated with the organic matter $20 \mathrm{~m}^{3}$ and mixed biofertilizer application being $157.5 \times 10^{5}$ cfu. /g dry soil. However, slight differences in total microbial counts with different forage crops. Maruit 1 exhibited the highest figure for total microbial counts which indicated that, Maruit 1 is well adapted to different environmental stress and highly response to biofertilization treatments application. The enhancement in microbial activity is good parameter for soil improvement indices. Plant growth promoting rhizobacteria (PGPR) like Azotobacter and Azospirillum produce growth promoting substance which enhance plant growth proliferation, lateral roots and root hairs which increase nutrient absorbing surface (Metin et. al.,2014). 
Table (8).Effect of organic matter rates, biofertilization treatments on microbial determinations at rhizosphere area of the studied forage crops. (Average of two seasons 2016 and 2017)

\begin{tabular}{|c|c|c|c|c|c|c|c|c|c|c|c|}
\hline \multirow[t]{2}{*}{ Genotypes } & \multirow{2}{*}{$\begin{array}{l}\text { OM } \\
\left(\mathbf{m}^{3}\right)\end{array}$} & \multirow{2}{*}{\begin{tabular}{|l} 
Biofertilization \\
treatments
\end{tabular}} & \multicolumn{3}{|c|}{$\begin{array}{c}\text { Total microbial counts } \\
\left(\times 10^{5} \mathrm{cfu} / \mathrm{g} \text { dry soil }\right)\end{array}$} & \multicolumn{3}{|c|}{$\begin{array}{l}\text { Azotobacter densities } \\
\quad\left(\times 10^{3} \text { cells/g dry soil }\right)\end{array}$} & \multicolumn{3}{|c|}{$\begin{array}{l}\text { Azospirillum counts } \\
\left(\times 10^{3} \text { cellsdry soil }\right)\end{array}$} \\
\hline & & & Cut $_{1}$ & $\mathrm{Cut}_{2}$ & $\mathrm{Cut}_{3}$ & Cut $_{1}$ & $\mathrm{Cut}_{2}$ & $\mathrm{Cut}_{3}$ & $\mathrm{Cut}_{1}$ & $\mathrm{Cut}_{2}$ & $\mathrm{Cut}_{3}$ \\
\hline \multirow{8}{*}{ 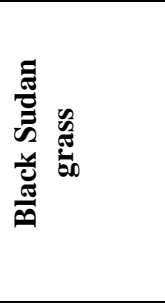 } & \multirow{4}{*}{10} & Control & 55 & 77 & 70 & 40 & 49 & 46 & 28 & 31 & 29 \\
\hline & & Azotobacter & 69 & 96 & 84 & 49 & 62 & 55 & 31 & 34 & 34 \\
\hline & & Azospirillm & 62 & 91 & 82 & 45 & 55 & 49 & 39 & 47 & 45 \\
\hline & & Mixture & 71 & 115 & 97 & 55 & 63 & 58 & 43 & 49 & 44 \\
\hline & \multirow{4}{*}{20} & Control & 68 & 82.6 & 74.5 & 45.9 & 59.2 & 53 & 31.6 & 36.7 & 34.7 \\
\hline & & Azotobacter & 84 & 120.4 & 109.1 & 60.2 & 72.4 & $\begin{array}{l}66.3 \\
\end{array}$ & 35.7 & 39.8 & 42.8 \\
\hline & & Azospirillm & 75.6 & 114.2 & 107.1 & 51 & 64.3 & 62.2 & 43.9 & 57.1 & 49 \\
\hline & & Mixture & 96.9 & 131.6 & 114.2 & 63.2 & 74.5 & 65.3 & 51 & 60.2 & 52 \\
\hline \multirow{8}{*}{ 离 } & \multirow{4}{*}{10} & Control & 67 & 78 & 71 & 53 & 62 & 54 & 39 & 44 & 39 \\
\hline & & Azotobacter & 76 & 103 & 94 & 65 & 74 & 75 & 48 & 56 & 41 \\
\hline & & Azospirillm & 69 & 98 & 91 & 62 & 68 & 66 & 57 & 64 & 59 \\
\hline & & Mixture & 88 & 116 & 98 & 73 & 79 & 81 & 61 & 69 & 63 \\
\hline & \multirow{4}{*}{20} & Control & 68.6 & 91.14 & 78.4 & 59.8 & 82.3 & 78.4 & 46.2 & 52.5 & 50.4 \\
\hline & & Azotobacter & 86.3 & 146 & 134.3 & 74.2 & 108.2 & 102.9 & 51.5 & 59.9 & 55.7 \\
\hline & & Azospirillm & 79.4 & 140.1 & 139.2 & 71.5 & 100.3 & 92.6 & 65.1 & 74.6 & 70.4 \\
\hline & & Mixture & 100 & 154.8 & 146 & 90.3 & 118.7 & 110.3 & 68.3 & 79.8 & 75.6 \\
\hline \multirow{8}{*}{ } & \multirow{4}{*}{10} & Control & 68 & 78 & 71 & 53 & 66 & 59 & 41 & 49 & 45 \\
\hline & & Azotobacter & 89 & 107 & 98 & 68 & 74 & 79 & 48 & 57 & 55 \\
\hline & & Azospirillm & 80 & 99 & 93 & 65 & 69 & 73 & 59 & 70 & 64 \\
\hline & & Mixture & 114 & 129 & 121 & 75 & 89 & 86 & 62 & 75 & 71 \\
\hline & \multirow{4}{*}{20} & Control & 81.9 & 98.7 & 94.5 & 62 & 82.9 & 78.6 & 45.1 & 52.9 & 50 \\
\hline & & Azotobacter & 121.8 & 153.3 & 136.5 & 75.6 & 105.8 & 96.1 & $\begin{array}{l}51.9 \\
\end{array}$ & 59.8 & $\begin{array}{l}57.8 \\
\end{array}$ \\
\hline & & Azospirillm & 107.1 & 144.8 & 128.1 & 73.5 & 101.9 & 88.2 & 62.7 & 74.5 & 71.5 \\
\hline & & Mixture & 146 & 157.5 & 151.2 & 91.2 & 123.5 & 110.7 & 65.7 & 80.4 & 78.4 \\
\hline \multicolumn{3}{|c|}{ D.at $0.05 \%$} & \multicolumn{3}{|c|}{1.539} & \multicolumn{3}{|c|}{0.184} & \multicolumn{3}{|c|}{0.342} \\
\hline
\end{tabular}


7.2. Azotobacter densities: Inoculation with heavy suspension of Azotobacter led to a rather pronounced increase in densities recorded at the $1^{\text {st }}$ and $2^{\text {nd }}$ cuts. The effect diminished with the prolongation of plant growth period. The lowest densities of Azotobacter (Table 8) were recorded at rate $10 \mathrm{~m}^{3}$ organic matter without biofertilization treatments(Control) . Slight difference in Azotobacter densities recorded with different forage crops; while Maruit 1 exhibited the highest value of Azotobacter densities. The promoting effect due to application of $\boldsymbol{A}$. chroococcum not only due to the nitrogen fixation but also to the production of plant growth promoting substances, production of amino acids, organic acids, vitamins and antimicrobial substances as well which increase soil fertility, microbial community and plant growth (Singh et. al. 2013).

7.3. Azospirillum densities: data in Table (8) showed the estimation of Azospirillum densities in rhizosphere area of the studied forage crops, Azospirillum densities tended to increase at the $1^{\text {st }}$ and $2^{\text {nd }}$ cuts, and then declined toward the third cut. Also for the organic matter addition $20 \mathrm{~m}^{3}$ and mixed biofertilization treatments recorded better values. Biofertilization with Azospirillum increased its densities in single and mixed treatment compared with the control treatment. These results agreed with that obtained by Abd El Gawad and Omar, (2014).

7.4. Enzymatic activities: Measurements of enzymatic activities in soil samples are critical index of soil fertility because enzymes play an important role in nutrient cycles (Anwesha et. al., 2012), data in Table (9) showed that the determination of enzymatic activity in rhizosphere area of the studied forage crops plants epresented the followings:

Dehydrogenase enzyme: Dehydrogenase activity (DHA) represents the energy transfer, therefore, it is considered as an index of overall microbial activity in the soil. Represented data in table 9 recorded that organic matter rates wihout biofertilizer application recorded lower values of DHA activity compared with biofertilization treatments and addition of $20 \mathrm{~m}^{3}$ organic matter. Interaction treatment of organic matter and biofertilization recorded the highest DHA activity. This may be due to that A.chroococcum and A.brasilence played an important role as plant growth promoting rhizobacteria via $\mathrm{N}_{2}$ fixation (Muthukumar and Udaiyan2006). This might led to accumulate available nutrients and stimulate the microorganisms in soil rhizosphere.

Nitrogenase activity: Nitrogenase activity in soil samples increased with different biofertilization treatments. The highest mean values of 
nitrogenase enzyme was recorded with the mixed biofertilization treatments with addition of $20 \mathrm{~m}^{3}$ organic matter. Many investigators demonstrated the positive effect of dual inoculation with $\mathrm{N}_{2}$-fixer on $\mathrm{N}_{2-}$ ase activity (El- Komy, 2005).

Table (9): Effect of Organic Matter rates and Biofertilization treatments on Enzymatic activities at rhizosphere area for the studied forage crops. (Average of two seasons 2016 and 2017)

\begin{tabular}{|c|c|c|c|c|}
\hline Genotypes & $\begin{array}{l}\mathbf{O M} \\
\left(\mathbf{m}^{\mathbf{3}}\right)\end{array}$ & \begin{tabular}{|l} 
Biofertilization \\
Treatments \\
\end{tabular} & $\begin{array}{c}\text { Dehydrogenase } \\
\mu \mathrm{IDHA} / \mathrm{g} \text { dry soil }\end{array}$ & $\begin{array}{c}\text { Nitrogenase } \\
\mu \mathrm{MC} 2 \mathrm{H} 4 \mathrm{~kg} / \mathrm{h}\end{array}$ \\
\hline \multirow{8}{*}{ 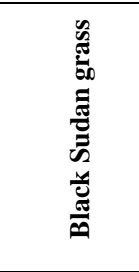 } & \multirow{4}{*}{10} & \begin{tabular}{|c|} 
Control \\
\end{tabular} & 0.55 & 0.25 \\
\hline & & Azotobacter & 0.91 & $\mathbf{0 . 5 8}$ \\
\hline & & Azospirillm & 0.75 & 0.66 \\
\hline & & Mixture & 0.98 & 0.89 \\
\hline & \multirow{4}{*}{20} & Control & 0.69 & 0.27 \\
\hline & & Azotobacter & 1.38 & 0.88 \\
\hline & & Azospirillm & 1.22 & 0.94 \\
\hline & & Mixture & 1.53 & 1.02 \\
\hline \multirow{8}{*}{ ¿ } & \multirow{4}{*}{10} & Control & 1.13 & 0.27 \\
\hline & & Azotobacter & 1.28 & 0.64 \\
\hline & & Azospirillm & 1.23 & $\mathbf{0 . 5 3}$ \\
\hline & & Mixture & 1.44 & 0.71 \\
\hline & \multirow{4}{*}{20} & Control & 1.41 & 0.59 \\
\hline & & Azotobacter & 1.58 & 1.06 \\
\hline & & Azospirillm & 1.46 & 1.19 \\
\hline & & Mixture & 1.82 & 1.28 \\
\hline \multirow{8}{*}{ 窇 } & & Control & 1.38 & 0.38 \\
\hline & & Azotobacter & 1.69 & 0.94 \\
\hline & & Azospirillm & 1.53 & 1.24 \\
\hline & & Mixture & 2.20 & 1.36 \\
\hline & & Control & 1.51 & 0.48 \\
\hline & & Azotobacter & 1.89 & 1.35 \\
\hline & & Azospirillm & 1.85 & 1.41 \\
\hline & & Mixture & 2.17 & 1.46 \\
\hline \multicolumn{3}{|c|}{ L.S.D at $0.05 \%$} & 0.2883 & 0.016 \\
\hline
\end{tabular}

\section{REFERENCES}

Abd El Gawad, A. M. (2008). Study the induction effect of Azospirillum inoculation on the formation of Para nodules on gramineae. Annals of Agric. Sci, Ain Shams Univ., Cairo, 53 (1): 91-103.

Abd El-Gawad, A.M. and S.A. Omar(2014) Effect of Biofertilization on the productivity of some Forage crops under water stress conditions. Egypt. J. of Appl. Sci., 29(2):55-80.

Ague, R. C. and G. H. Palmer (2007). Effect of mashing procedures on some sorghum varieties germinated at different temperatures. J. Sc. Agri., London Swipe, 32 (2): 147-158.

Ahmed Amal E. and Mona M. El-Shazly (2018).Using of Bio and Micronutrients Fertilization on improving Productivity of some 
Summer Fodder Crops at Ras Sudr Area.1st International Scientific Conference" Agriculture and Futuristic Challenges" Fac. of Agric.-Cairo, Al-Azhar Univ, Nasr City, Cairo, Egypt. April 10th -12th , 2018,Vol.1(11),pp:585-598.

Almodares, A. ; M.R. Hadi and B. Dosti (2008). The effects of salt stress on growth parameters and carbohydrates contents in sweet sorghum. Res. J. Environ. Sci., 2(4): 298-304.

Azim, K. ; B. Soudi ; S. Boukhari ; C. Perissol ; S. Roussos and I.T. Alami (2018). Composting parameters and compost quality: a literature review. Organic agriculture, 8(2): 141-158.

Bagheri, A.R. (2011). Effect of salinity and inoculation with Azospirillum on carbohydrate production, nitrogen status and yield of barley. African J. of Biotechnology, 10 (45): 90899096.

Bashan, Y. and L.E. de-Bashan (2010). How the plant growthpromoting bacterium Azospirillum promotes plant growth a critical assessment. Adv. Agron., 108: 77-136.

Bashan, Y.; G. Holguin and L.E. de-Bashan (2004). Azospirillumplant relationships: physiological, molecular, agricultural, and environmental advances (1997-2003).Can. J. Microbial., 50: 521-577.

Bhardwaj, D. ; M.W. Ansari and R.K. Sahoo and N.Tuteja (2014) Biofertilizers function as key player in sustainable agriculture by improving soil fertility, plant tolerance and crop productivity. Microbial Cell Fact, 13 (66):1-10.

Bhivare, V.N. and J.D. Nimbalkar (1984). Salt stress effects on growth and mineral nutrition of French beans. Plant and Soil, 80: 91-98.

Bremner, J.M. and C.S. Mulvaney (1982). Nitrogen-Total. In: A. L. Page, R. H. Miller (Eds.). Methods of Soil Analysis. Part 2. $2^{\text {nd }}$ ed. Agron. Monogr. 9. ASA and SSSA, Madison, WI, pp: 595-624.

Casida, L.E. ; D.A. Klein and T. Santoro (1964).Soil dehydrogenase activity. Soil Sci., 98: 371-378.

Ei-Lattief, E. A. (2016). Use of Azospirillum and Azobacter bacteria as biofertilizers in cereal crops: A review. International Journal of Research in Engineering and Applied Sciences (IJREAS), 6(7): 36-44.

El-Komy, H.M.A. (2005). Coimmobilization of Azospirillum lipoferum and Bacillus megaterium for successful phosphorus and 
nitrogen nutrition of wheat plants. Food Technol. Biotechnol., 43 (1): 19-27.

El-Sersawy, M.M. ; E.A. Bakhoum and N.N. Michail (1995). The role of organic manuring in ameliorating soil properties and wheat production of Wadi Sudr, South Sinai Egypt J. Appl. Sci., 10 (8): 602-622.

El-Sherbiny, W.A. and A.A. Abed El- Lateef (2009). Effect of Irrigation Intervals and Organic Fertilization on Soil Physical Properties and Sorghum Growth in Wadi Sudr Area, Sinai, Egypt. Journal of Applied Sciences Research, 5 (12): 2553-2562

FAOSTATE, (2013). C. F. http//www.faoorg/faostat

Farooq, M. ; M. Hussain ; A. Wakeel and K.H. Siddique (2015). Salt stress in maize: effects, resistance mechanisms, and management. A review. Agronomy for Sustainable Development, 35(2): 461-481.

Flowers, T.J. and S.A. Flowers (2005). Why does salinity pose such a difficult problem for plant breeders? Agric Water Manag, 78:15-24.

Haahtela, K. ; T. Wartiovaara and V. Sundman (1981). Rootassociated $\mathrm{N}_{2}$ fixation (acetylene reduction) by Enterobacteriaceae and Azospirillum strains in cold- climate spodsols. Appl Environ. Microbiol, 41: 203-206.

Hungria, M.; R.J.Campo ; E.M. Souza and F.O. Pedrosa (2010). Inoculation with selected strains of Azospirillum brasilense and A. lipoferum improves yields of maize and wheat in Brazil. Plant \& Soil, 331 (1-2): 413-424.

Indira, S. and S.J. Singh (2014): Effect of vermicompost and bio fertilizer on yield and quality of rabi onion (Allium cepa L) cv. puna red. - Agric. Sci. Digest., 34(2): 144-146.

Jain, V.; S. Khetrapal ; S. Aravind and S.P. Saikia (2010). Enhanced levels of soil nitrogen and endogenous phytohormones in maize (Zea maize L.) inoculated with Azospirillum brasilense. . Indian Journal of Plant Physiology, 15 (2): 0019-5502.

Khaton, M.A. ; A. Sagar ; J.E. Tajkia ; M.S. Islam ; M.S. Mahmud and A.K.M.Z. Hossain (2016). Effect of moisture stress on morphological and yield attributes of four sorghum varieties. Progressive Agriculture, 27(3): 265-271.

Kim, J.G.; M.S. Han and H.J. Han (2000). Studies on growth characteristics and dry matter accumulation of millet and 
sorghum varieties. Fourth Asian crop Sci., Conf., Seoul, Korea, pp: 485-497.

Kumar, V. ; V. Shriram ; P.B. KaviKishor ; N. Jawali and M.G. Shitole (2010) Enhanced proline accumulation and salt stress tolerance of transgenic indica rice by over expressing P5CSF129A gene. Plant Biotech Rep., 4: 37-48.

Mantelin, S. and B. Touraine (2004). Plant growth-promoting bacteria and nitrate availability: impacts on root development and nitrate uptake. Journal of experimental Botany, 55(394): 27-34.

Metin, T.; E. Melek ; Y. Ertan ; G. Adem ; K. Kenan ; K. Recep and D. Atilla (2014). Plant growth-promoting rhizobacteria improved growth, nutrient,and hormone content of cabbage (Brassica oleracea) seedlings. Turk J Agric For., 38: 62-69.

Muchow, R. (1989). Comparative productivity of maize, sorghum and pearl millet in a semi arid tropical environment. II. Effect of water deficit. Field Crops Res., 20: 207-219.

Munns, R. (2005). Genes and salt tolerance: bringing them together. New phytologist, 167(3): 645-663.

Munns, R. and M. Tester (2008). Mechanisms of salinity tolerance. Annu. Rev. Plant Biol., 59, 651-681.

Muthukumar, T. and K. Udaiyan (2006). Growth of nursery-grown Bamboo inoculated with arbuscular mycorrhizal fungi and plant growth promoting rhizobacteria in two tropical soil types with and without fertilizer application. New Forests, 31(3):469-485.

Netondo, G.W. ; J.C. Onyango and E. Beck (2004). Sorghum and salinity: I. Response of growth, water relations, and ion accumulation to $\mathrm{NaCl}$ salinity. Crop science, 44(3): 797-805.

Niu, G. ; W. Xu ; D. Rodriguez and Y. Sun (2012). Growth and physiological responses of maize and sorghum genotypes to salt stress. International Scholarly Research Notices, 2012.

Page, A.L.; R.H. Miller and D.R. Keeney (1982). Methods of Soil Analysis. $2^{\text {nd }}$ Ed, American Society of Agronomy, Madison, WI., USA.

Pidello, A. (2011). Ecología Microbiana- Química redox. Corpus, Rosario, Argentina, 144 pp.

Reddy, B.V. ; A. Ashok Kumar and P. Sanjana Reddy (2010). Recent advances in sorghum improvement research at ICRISAT. Kasetsart Journal (Natural Science), 44: 499-506. 
Roy, R.C. ; A. Sagar ; J.E. Tajkia ; M.A. Razzak and A.Z. Hossain (2018). Effect of salt stress on growth of sorghum germplasms at vegetative stage. Journal of the Bangladesh Agricultural University, 16(1): 67-72.

Russel, D.F. (1991). MSTAT C, Director. Crop and Soil Sciences Dept. Michigan State Univ. U.S.A.

Singh, K.N. and R. Chatrath (2001). Salinity tolerance. In: Reynolds, M.P.,Monasterio, J.I.O., McNab, A. (Eds.), Application of Physiology in Wheat Breeding. CIMMYT, Mexico, DF, pp. 101-110.

Singh, N. K.; F.K. Chaudhary and D.B. Patel (2013). Effectiveness of Azotobacter bio-inoculant's for wheat grown under dry land condition. Journal of Environmental Biology., 34: 927-932

Steenhoudt, O., and Vandereyden, J. (2000). Azospirillum, free-living nitrogen fixing bacterium closely associated with grasses: genetic, biochemical and ecological aspects. FEMS Microbiol. Rev. 24, 487-506. doi: 10.1111/j.1574-6976.2000.tb00552.x

Türkan, I. and T. Demiral (2009). Recent developments in understanding salinity tolerance. Environmental and Experimental Botany, 67(1): 2-9.

Yasmeen, A. ; S.M.A. Basra ; M. Farooq ; H. Rehman ; N. Hussain and H.R. Athar (2013) Exogenous application of moringa leaf extract modulates the antioxidant enzyme system to improve wheat performance under saline conditions. Plant Growth Regul., 69:225-233.

Zerbini, E. and D. Thomas (2003). Opportunities for improvement of nutritive value in Sorghum and Pearl millet residues in South Asia through genetic enhancement. Field Crop Res., 84: 3-15.

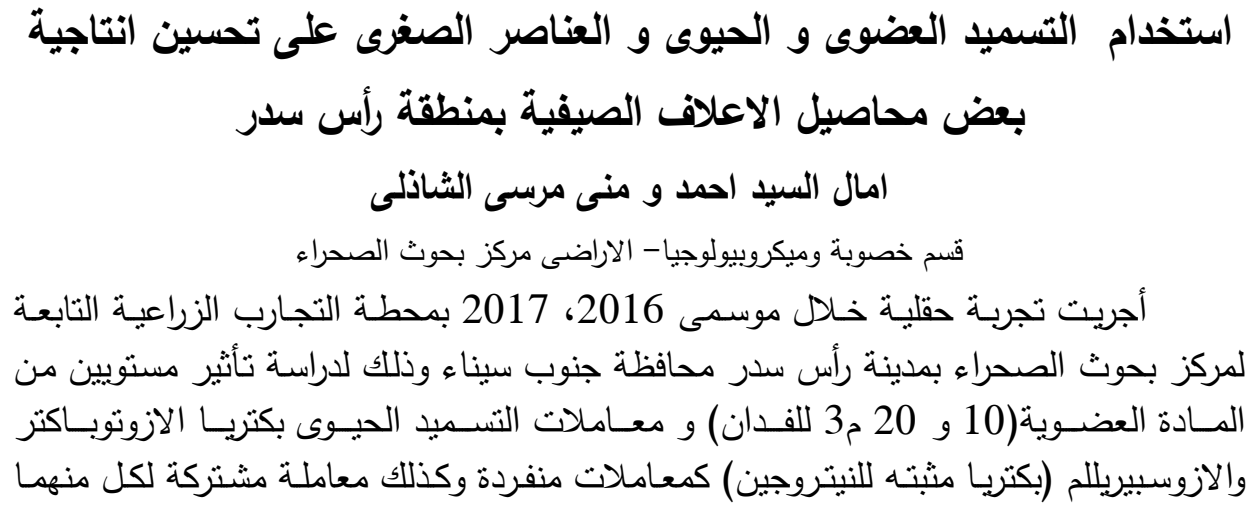




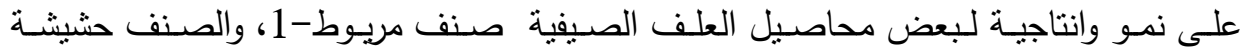
السودان السوداء، والدخن تحت ظروف الأراضى الجيرية و المتأثرة بالملوحة بمنطقة رأس سدر جنوب سيناء.

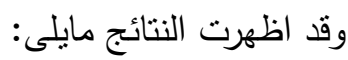

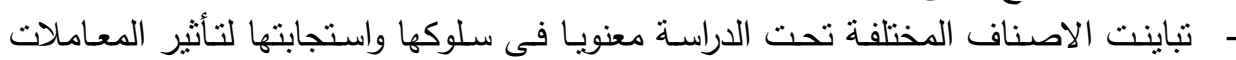

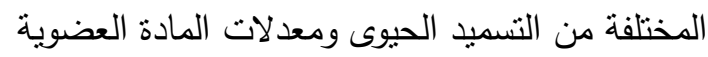

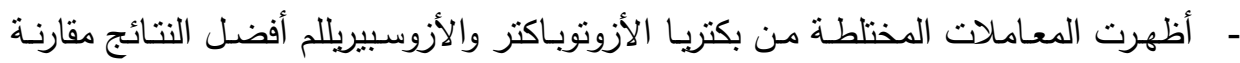

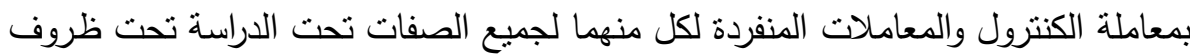

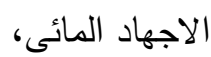

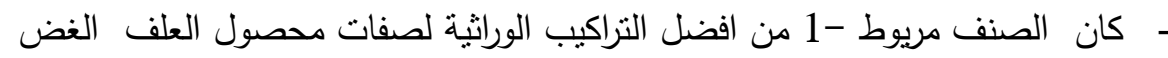

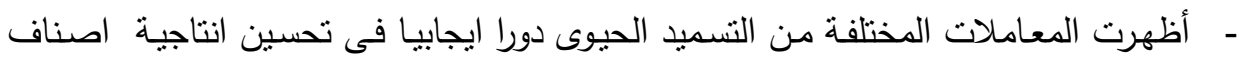

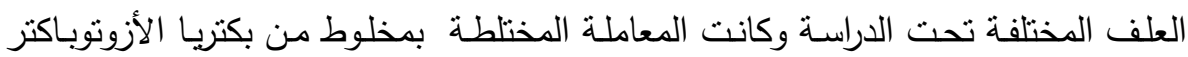

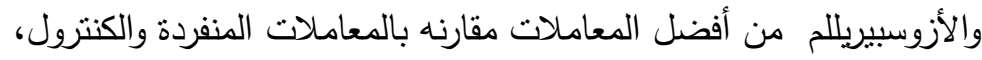

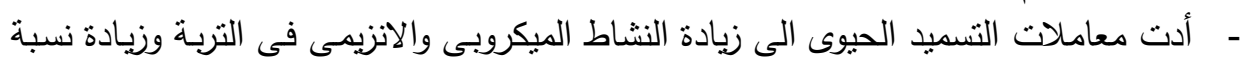

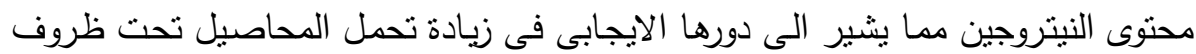
الاجهادات البيئية المختلفة.

توصى الدراسة باستخدام المعاملة المختلطة لكل من بكتريا الأزوتوباكتر والأزوسبيريللم

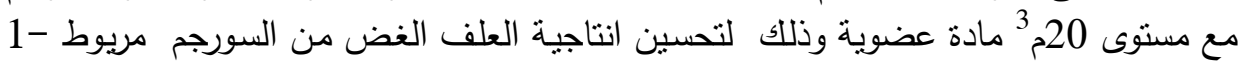

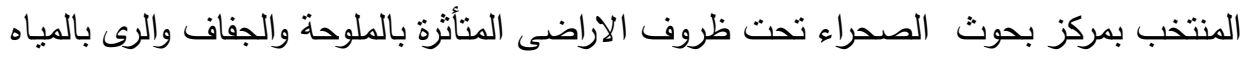

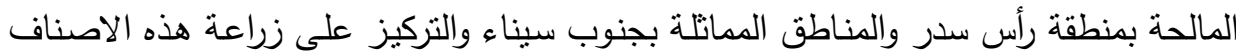
نظرا لزيادة تحملها لظروف الإجهاد المائى والملوحة وإستجابتها للتسميد الحيوى. 